\title{
Duplicate filum terminale noted in an adult: a rare finding
}

\author{
Justin R. Davanzo, MD, ${ }^{1}$ J. Christopher Zacko, MD, ${ }^{1}$ Charles S. Specht, MD, ${ }^{2}$ and \\ Elias B. Rizk, MD1 \\ Departments of ${ }^{1}$ Neurosurgery and ${ }^{2}$ Pathology, Penn State Hershey Medical Center, Hershey, Pennsylvania
}

\begin{abstract}
This is the first reported case of an adult presenting with tethering symptoms, limb discrepancy on physical examination, a low-lying spinal cord, and duplicate filum terminale discovered intraoperatively. Intraoperative imaging and pathological analysis of a specimen confirmed the diagnosis of duplicate filum. This is the first reported adult case with duplication of the filum terminale. Release of both fila was necessary in this case to relieve the tethering symptoms.
\end{abstract}

http://thejns.org/doi/abs/10.3171/2016.2.SPINE15759

KEY WORDS filum terminale; spinal cord tethering; congenital

$\mathrm{N}$ EURAL tube defects (NTDs) come in a variety of subsets. Patients with NTDs can present with different signs and symptoms. One of the rarest NTD subsets is the split cord malformation (SCM). ${ }^{1,6,7,9,10,12-14}$ Rarer still is the finding of duplicate filum terminale, either on preoperative imaging or intraoperatively, especially in the absence of a split cord formation. This finding is rare in children and unreported in adults at this point. ${ }^{2}$ Here we describe the first reported case of duplicate filum terminale in the setting of a tethered cord in an adult.

\section{Case Report}

History and Examination

A 43-year-old man presented to our clinic with a longstanding history of lower thoracic and lumbar spine pain. In addition, he had approximately 15 years of atrophy of the left calf with some plantar flexion weakness of the left foot as well. Imaging showed Grade 2 spondylolisthesis of the L5-S1 space, bilateral L-5 pars defects, and a tethered cord with a low-lying conus behind the L5-S1 disc space (Fig. 1). Flexion and extension radiographs did not show evidence of dynamic instability. His neurological ex- amination at that time revealed Medical Research Council grade 4/5 weakness in left-sided plantar flexion and calf atrophy. Urodynamic studies were also performed, and the findings were more consistent with benign prostatic hypertrophy than with neurogenic bladder. After completion of these studies, the patient decided to proceed with the cord detethering procedure.

\section{Operation}

A laminectomy was performed from the L-4 to S-1 levels. Intraoperatively, we noted that the patient had duplicate filum terminale (Fig. 2). Both were stimulated intraoperatively and confirmed to be nonfunctional. Both fila were then sectioned and sent to pathology for diagnostic confirmation (Fig. 3).

\section{Postoperative Course}

Approximately 1 month postoperatively, the patient did develop a pseudomeningocele requiring a reoperation for the repair of a dural defect. The patient was then seen in follow-up approximately 2 weeks later, with resolution of the pseudomeningocele. In addition, his back pain significantly improved postoperatively. 


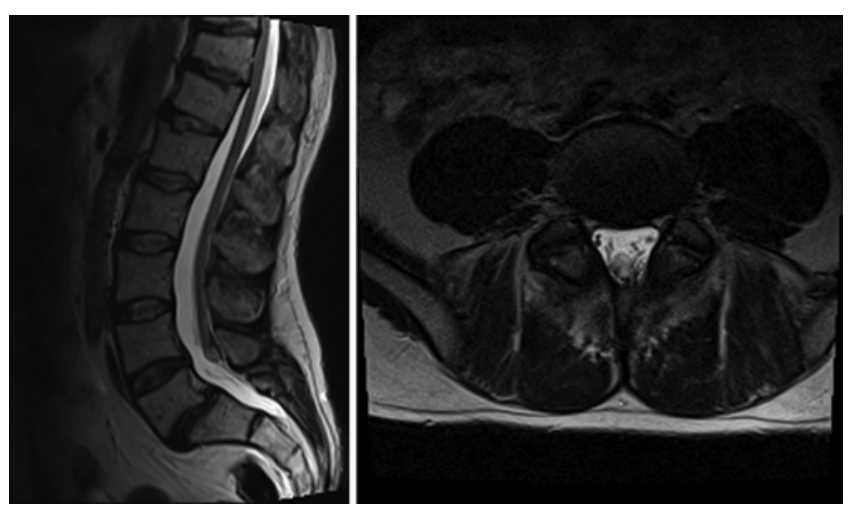

FIG. 1. Preoperative sagittal (left) and axial (right) T2-weighted MR images showing a low-lying spinal cord and conus.

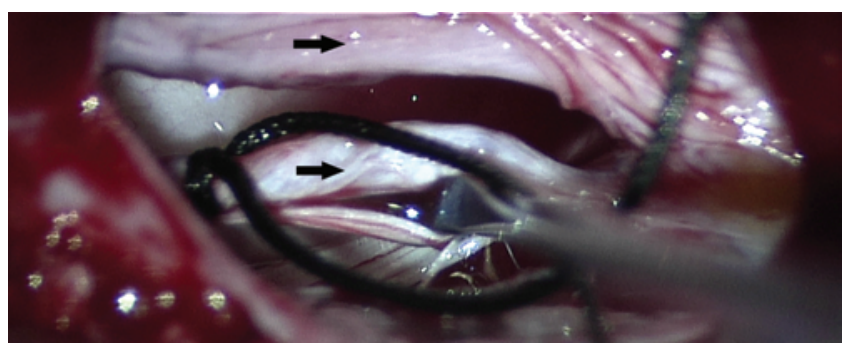

FIG. 2. Intraoperative photograph showing duplicate filum terminale (black arrows). Figure is available in color online only.

\section{Discussion}

Here we reported on the first adult case of duplicate filum terminale causing spinal cord tethering. Despite several reports of this finding in children, there are currently no reported instances of duplicate filum terminale as the cause of cord tethering in an adult. Our patient presented with clinical and radiographic findings consistent with a tethered spinal cord. While the imaging findings for this patient did not really suggest duplicate filum, the intraoperative and pathological findings were certainly consistent with this disorder. As previously reported, if this finding is not addressed in the detethering procedure, the procedure could fail to address tethering of the spinal cord. ${ }^{13}$

To understand the pathology behind an SCM and duplicate filum terminale, it is important to review the embryological development of the filum terminale. The caudal cell mass is the embryological structure that gives rise to both the filum terminale and ventriculus terminalis. Around the 52nd day of gestation, the caudal neural tube regresses between the ventriculus terminalis and the caudal cell mass. This, in turn, gives rise to the structure that will become the filum terminale. Eventually, the secondary neuroectodermal cells will differentiate into a fibrous layer in this region, creating the filum terminale. ${ }^{11}$

Bentley and Smith became the first group to describe SCM as a spinal cord malformation. ${ }^{2}$ However, they were not able to give any developmental explanation for this interesting and clinically relevant finding. In 1940, several theories were published regarding the development of an SCM. Lichtenstein believed it was most consistent with an abnormality in the development of the mesoderm. ${ }^{8}$ Another paper published by Herren and Edwards around the same time suggested this finding was more consistent with tissue overgrowth. ${ }^{5}$ These theories were challenged by Gardner in $1968 .^{3}$ His theory centered on hydromyelia causing a split in the caudal portion of the spinal cord. In 1971, Hendrick made another hypothesis that involved an accessory neurenteric canal leading to the malformation. ${ }^{4}$ Finally, in 1992, Pang et al. presented a unifying theory of the development of an SCM. They proposed that these malformations were the result of one basic error in development around the time of closure of the primitive canal. ${ }^{12}$ The finding of duplicate filum is so rare that whether this finding is a type of SCM or its own separate entity is poorly understood at this point.

\section{Conclusions}

Tethering of the spinal cord could be the result of duplicate filum terminale in both pediatric and adult patients.

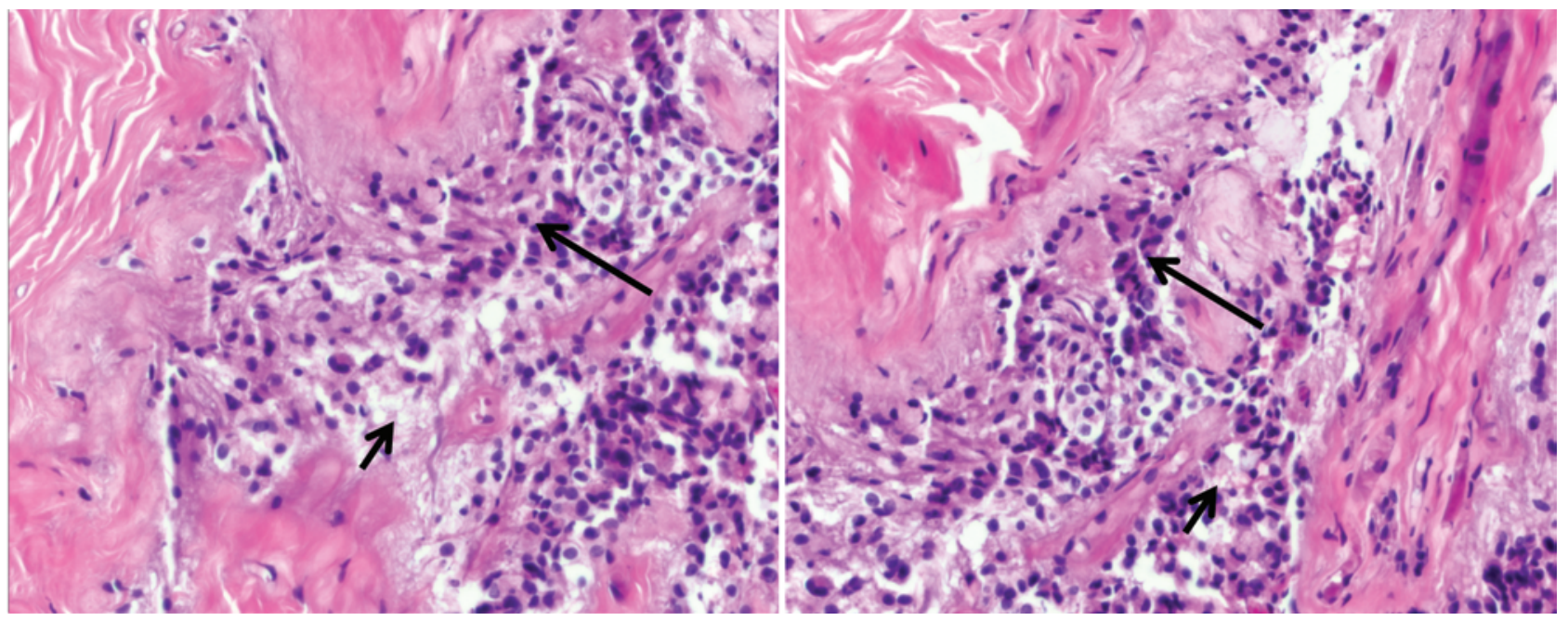

FIG. 3. Histopathological slides showing findings consistent with filum terminale. Long arrows indicate gliotic tissue. Short arrows indicate adipose tissue. Figure is available in color online only. 


\section{References}

1. Ansari S, Nejat F, Yazdani S, Dadmehr M: Split cord malformation associated with myelomeningocele. J Neurosurg 107 (4 Suppl):281-285, 2007

2. Bentley JF, Smith JR: Developmental posterior enteric remnants and spinal malformations: the split notochord syndrome. Arch Dis Child 35:76-86, 1960

3. Gardner WJ: Myelocele: rupture of the neural tube? Clin Neurosurg 15:57-79, 1968

4. Hendrick E: On diastematomyelia. Prog Neurol Surg 4:277-288, 1971

5. Herren R, Edwards J: Diplomyelia (duplication of the spinal cord). Arch Pathol (Chic) 30:1203-1214, 1940

6. Higashida T, Sasano M, Sato H, Sekido K, Ito S: Myelomeningocele associated with split cord malformation type Ithree case reports. Neurol Med Chir (Tokyo) 50:426-430, 2010

7. Jindal A, Mahapatra AK: Split cord malformations-a clinical study of 48 cases. Indian Pediatr 37:603-607, 2000

8. Lichtenstein B: Spinal dysraphism. Spina bifida and myelodysplasia. Arch Neurol Psychiatry 44:794-810, 1940

9. Mahapatra AK: Split cord malformation-a study of 300 cases at AIIMS 1990-2006. J Pediatr Neurosci 6 (Suppl 1):S41-S45, 2011

10. Mahapatra AK, Gupta DK: Split cord malformations: a clinical study of 254 patients and a proposal for a new clinicalimaging classification. J Neurosurg 103 (6 Suppl):531-536, 2005

11. Nievelstein RA, Hartwig NG, Vermeij-Keers C, Valk J: Embryonic development of the mammalian caudal neural tube. Teratology 49:445, 1994
12. Pang D, Dias MS, Ahab-Barmada M: Split cord malformation: Part I: A unified theory of embryogenesis for double spinal cord malformations. Neurosurgery 31:451-480, 1992

13. Rizk E, Adeeb N, Hussein AE, Tubbs RS, Rozzelle CJ, Oakes WJ: Duplicated filum terminale in the absence of split cord malformation: a potential cause of failed detethering procedures. Childs Nerv Syst 30:709-711, 2014

14. Sinha S, Agarwal D, Mahapatra AK: Split cord malformations: an experience of 203 cases. Childs Nerv Syst 22:3-7, 2006

\section{Disclosures}

The authors report no conflict of interest concerning the materials or methods used in this study or the findings specified in this paper.

\section{Author Contributions}

Conception and design: Rizk, Davanzo. Acquisition of data: Rizk, Davanzo, Specht. Analysis and interpretation of data: Rizk, Davanzo. Drafting the article: Rizk, Davanzo. Critically revising the article: Rizk, Zacko. Reviewed submitted version of manuscript: Rizk. Approved the final version of the manuscript on behalf of all authors: Rizk. Administrative/technical/material support: Rizk. Study supervision: Rizk.

\section{Correspondence}

Elias B. Rizk, Department of Neurosurgery, Penn State Hershey Medical Center, EC 100, 30 Hope Dr., Hershey, PA 17033. email: erizk@hmc.psu.edu. 